\section{UK study reaffirms view of no 'safe' level of radiation}

A report by the UK National Radiological Protection Board that assesses the risk of inducing cancer at low doses and low-dose rates of radiation has reaffirmed the view that radiation protection should be based on the assumption that there is no safe level of radiation. It concludes that any exposure to ionizing radiation carries the risk of cancer-inducing damage to DNA.

This has been the viewpoint of both the national and international radiological protection boards for some time but appeared to be called into question by the findings of an earlier report, published last autumn and commissioned by the French government, which stated there is a dose threshold below which radiation has no effect. It had been suggested that because of the level of single-strand DNA damage that arises spontaneously in cells, the small increment of damage induced by low-dose radiation is insignificant for cancer risk. The government-funded radiation protection board performed the study under contract to its French counterpart, the Institut de Protection et de Sûreté Nucléaire, which had asked for an independent review of the available evidence to sort out the contradictory findings.

The latest study looks at data from the Life Span Study of the survivors of the atomic bombings of Hiroshima and Nagasaki in 1945, studies of radiation workers both in the UK and elsewhere, animal data, and studies on the effects of radiation at the cellular level.

John Stather, one of the authors of the response." at the end of November. report, says that interpretation of epidemiological and experimental studies at low doses is being increasingly influenced by accumulating information on the fundamental nature of the tumorigenic process (see below). The critical damage caused by radiation is likely to be coincidental damage to both DNA strands (DNA double-strand breaks). The argument that damage to DNA caused by low-dose radiation does not increase cancer risk "is not sustainable", the report finds, because it fails to recognize the very low incidence of spontaneous DNA double-strand (as opposed to singlestrand) damage and "the critical importance of these lesions and their misrepair for cellular radiobiological

"A single radiation track traversing the nucleus of an appropriate target cell has a finite probability, albeit very low, of generating the specific damage to DNA that can result in development of a tumour," says Stather. In other words, there is no dose threshold below which risk of tumour induction would be zero.

Although the radiation protection board is responsible for assessing risks and not for setting thresholds, it recommends that the use of thresholds should be replaced by the concept of a progressive increase in risk with increasing dose. National Radiological Protection Board Director Roger Clarke will present the report's findings to the French government

Nuala Moran London

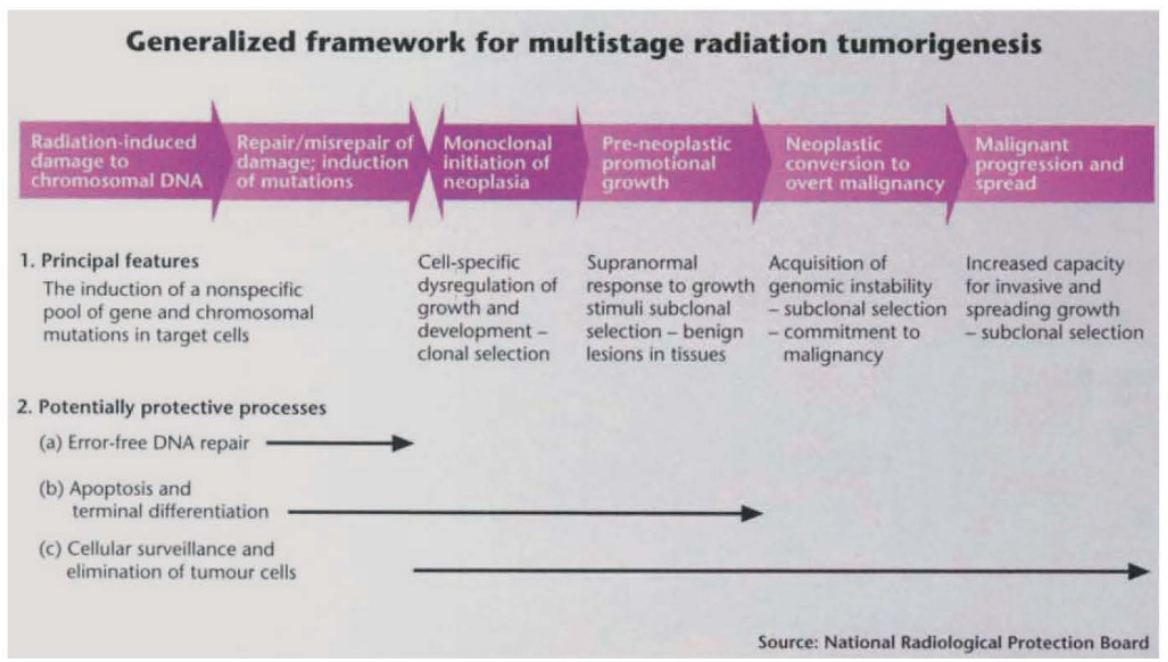

\section{DID YOU KNOW?}

\section{French government shake-up}

Alain Juppé, the prime minister of France, announced on 7 November a major government reshuffle. Although the key ministers emerged unscathed, the streamlining exercise saw the number of top government posts cut from 41 to 32 . As part of the re-organization, four of the positions were filled from outside, 13 ministers and secretaries of state were ousted, and only four of the twelve women that formed part of Juppé's first government held on to their old positions or were given new ones.

Elizabeth Dufourcq, appointed secretary of state for research last May, has been replaced by François d'Aubert, secretary of state for the budget in the previous government. Research will remain part of the Ministry of National Education and Research. However, there will no longer be an autonomous public health ministry. Matters of public health will now fall under the jurisdiction of a superministry for social affairs and labour, under former labour minister Jacques Barrot.

CATHERINE TASTEMAIN Paris

\section{Indian gynaecologists push for ban on paid egg donation} The Indian government, which last year banned the sale of human organs in an effort to stop the illicit trade in kidneys, is being asked to step in again and make paid egg donation and payments to surrogate mothers illegal. Demand for both is increasing, said some Indian gynaecologists at a recent meeting on medical ethics held in New Delhi, organized by the Max Mueller Centre of the German Embassy and the All-India Institute of Medical Sciences, both in New Delhi. They warned that a new racket could emerge unless regulations are introduced to control these practices.

Anywhere from Rs 10,000 to 30,000 (US\$300 to $\$ 900$ ) is the going rate for egg donation, according to Indira Hinduja of the Hinduja Hospital in Bombay. Hinduja headed the team that 15 years ago produced India's first test-tube baby. "My woman patients are ready to do anything and pay any amount to get a baby because a childless woman does not get respect in an Indian household," Hinduja said at the meeting. "This has put us in a moral dilemma whether or not to encourage paid egg donors and surrogacy for a fee."

K.S. JAYARAMAN New Delhi 